\title{
THE ANALYSIS OF PROBLEMS ENCOUNTERED BY BEGINNER WRITER IN WRITING A SHORT STORY: A Case Study in Creative Writing Class
}

\author{
N. Y. Pratiwi \\ Pendidikan Bahasa Inggris, Universitas Pendidikan Ganesha, Singaraja \\ e-mail: npratiwi.yulia@gmail.com
}

\begin{abstract}
Creative process is the journey that a writer takes in order to create a piece of creative writing. During this process a writer, especially a beginner writer, encountered numerous obstacles which influence the writing performance. This study was aimed to analyze the problems faced by the students of Creative Writing course in Ganesha University of Education and describe how the students deal with the problems. The problems analyzed consist of three major aspects of writing fiction, namely literature elements, technical problems, and students' self-perception. The study found out that the majority of the students experienced similar problems from certain elements, meanwhile there were also problems found that appeared to be different from one another. This leads to further findings that the students conducted various attempts to deal with the problems.
\end{abstract}

Keywords : Creative Process, Creative Writing, problems, attempts

\section{Introduction}

Creativity is the ability to bring some qualities such as originality, extraordinariness, in a certain composition, creating a new experiences and new ideas and thoughts (Temizkan, 2011). It emphasizes on how the new thoughts and ideas connected together into a new information that makes sense. For this reason, creativity and writing skill are closely related to one another and leads to the term creative writing.

Creative writing is defined as writing in an open space with endless possibility and freedom of imagination (Morley, 2007). It requires learners to manipulate the language in attractive, interesting, and demanding ways in an attempt to express uniquely personal meanings (Tok \& Kandemir, 2015). Thus, writing has an important contribution to the development of other skills and also becomes a tool to express person's feelings, thoughts and information. Therefore, writing should be perceived as a skill which covering understanding, thinking, developing and producing skills. These skills are known as creative process.

Creative process is the journey that a writer takes in order to create a piece of creative writing. Brien (2006) states that the creative process commonly begins with a reading as a form of research conducted in order to gather information. The process is later continued with writing, and finally publishing. Furthermore, Vickers (2010) collaborate the creative process in writing fiction as both creative and interpretive process. The process is divided into four stages which begin with reading nonfictional text as an inspiration. Although there are four stages, Vickers (2010) also emphasized that in most of creative processes, nothing is really predictable and measured exactly, as he states that 'one never knows what thoughts, happening, and connections the mind will make until we are in the middle of things'. It implies that a creative process for each person is different according to their style of learning. 
However, a writer who is just beginning to learn how to write might find some problems during the creative process. These problems can be from several factors, they are from the elements of prose fiction, linguistic factors, and self-perception factors. Therefore, here the researcher intends on analyzing the problems faced by the students in writing fiction during the Short Story Production class, thus analyzing the students' solution in dealing with these problems..

\section{Method}

This research is a qualitative research which specify on the case study research design. this research was conducted in English Language Education department of Ganesha University of Education with the focus on Short Story Production class. The Short Story Production Class is a part of Creative Writing course, a specific concentration course which aims to teach the students in English Language Education department to be a writer in the actual and professional context. In this class, the students encountered several creative processes and problems in producing short stories which makes this class fulfill the requirement of having a specific phenomenon for a case study research and it is possible to be the subject of this study. The population of this research is the students of Short Story Production class which consists of 13 students. The data for this research was taken by using semi-structured interviews.

\section{Findings and Discussions}

During the process on writing, the researcher intended to analyze the problem encountered by the students in Short Story Production class. Based on the data gathered, the researcher found findings regarding to the problem. The problem formulated in this research is divided into three aspects, namely elements of literature, linguistic, and selfperception factors. These issues are presented as corpus data. There will be 13 corpus data for discussing each of the respondents' answer. Here is the table which shows the mapping of the respondents' problem as a summary.

Table 1. The Summary of the Problem Encountered by the Respondents

\begin{tabular}{|c|c|c|c|c|c|c|c|c|c|c|c|c|}
\hline \multirow{2}{*}{$\begin{array}{l}\text { Data } \\
\text { Corp } \\
\text { us/P } \\
\text { robl } \\
\text { em }\end{array}$} & \multicolumn{5}{|c|}{ Literature Elements } & \multicolumn{3}{|c|}{ Technical Problems } & \multicolumn{3}{|c|}{$\begin{array}{l}\text { Students Self- } \\
\text { Perception }\end{array}$} & \multirow{2}{*}{$\begin{array}{l}\mathrm{N} \\
\text { ot } \\
\mathrm{e}\end{array}$} \\
\hline & $\begin{array}{l}\text { Plo } \\
\mathrm{t}\end{array}$ & $\begin{array}{l}\text { Chara } \\
\text { cteriz } \\
\text { ations }\end{array}$ & $\begin{array}{l}\text { Th } \\
\text { em } \\
\text { e }\end{array}$ & $\begin{array}{l}\text { Setti } \\
\text { ngs }\end{array}$ & $\begin{array}{l}\text { PO } \\
V\end{array}$ & $\begin{array}{l}\text { Gra } \\
\mathrm{mm} \\
\mathrm{ar}\end{array}$ & $\begin{array}{l}\text { Sente } \\
\text { nce } \\
\text { Struct } \\
\text { ure }\end{array}$ & $\begin{array}{l}\text { Word } \\
\text { Choic } \\
\text { e }\end{array}$ & $\begin{array}{l}\text { Distr } \\
\text { actio } \\
\text { ns }\end{array}$ & $\begin{array}{l}\text { Write } \\
\text { r's } \\
\text { Block }\end{array}$ & $\begin{array}{l}\text { Moo } \\
\text { d }\end{array}$ & \\
\hline 1 & Yes & Yes & Yes & Yes & Yes & Yes & No & Yes & Yes & Yes & Yes & \\
\hline 2 & Yes & Yes & No & $\begin{array}{l}\text { Und } \\
\text { ecid } \\
\text { ed }\end{array}$ & No & Yes & $\begin{array}{l}\text { Undec } \\
\text { ided }\end{array}$ & No & Yes & Yes & Yes & \\
\hline 3 & Yes & Yes & No & Yes & No & Yes & Yes & Yes & No & Yes & No & \\
\hline 4 & No & No & Yes & No & No & $\begin{array}{l}\text { Und } \\
\text { ecid } \\
\text { ed }\end{array}$ & Yes & No & Yes & Yes & Yes & \\
\hline 5 & Yes & Yes & Yes & Yes & Yes & Yes & Yes & Yes & Yes & Yes & Yes & \\
\hline 6 & Yes & Yes & No & Yes & No & No & No & $\begin{array}{l}\text { Undec } \\
\text { ided }\end{array}$ & Yes & Yes & Yes & \\
\hline 7 & No & No & Yes & Yes & No & Yes & Yes & No & Yes & Yes & Yes & \\
\hline 8 & No & No & Yes & No & No & Yes & Yes & Yes & No & Yes & No & \\
\hline
\end{tabular}




\begin{tabular}{llllllllllll}
\hline 9 & Yes & No & No & No & Yes & Yes & Yes & Yes & Yes & Yes & $\begin{array}{l}\text { Und } \\
\text { ecid } \\
\text { ed }\end{array}$ \\
10 & Yes & Yes & No & No & No & Yes & Yes & Yes & Yes & Yes & Yes \\
11 & Yes & Yes & Yes & Yes & Yes & Yes & Yes & No & Yes & Yes & No \\
12 & Yes & Yes & Yes & Yes & Yes & Yes & Yes & Yes & Yes & Yes & Yes \\
13 & Yes & Yes & Yes & Yes & No & Yes & Yes & No & Yes & Yes & Yes \\
\hline
\end{tabular}

The table above shows the total number of the problem encountered by the respondents. There are 11 issues in total, namely Plot, Characterizations, Theme, Settings, Point of View, Grammar, Sentence Structure, Word Choice, Distractions, Writer's Block, and Mood. In the table above, it is shown that there are three kinds of responses obtained from the respondent. Yes indicates that the students finds the issues as problematic, No signify that the students did not have a problem with the addressed issues, and Undecided implies that the students cannot decide whether the issue addressed was problematic or not, and therefore is not counted as a problem.

It is shown that each of the respondents has their own problems in the process of writing short story. There are the elements that became problems for one respondent, but were not considered as an issue for the other respondent and vice versa. Similarly, the elements which became a problem for many respondents did not cause the exact same problem between the respondents, which further caused different ways of coping with it.

In the process of writing the story, it is found that the majority of the students had problems with the design of the plot for the story, covering $77 \%$ of the respondents. These problems are mostly caused by the students' difficulties in finding a unique theme that might be interesting for the target reader. About $66 \%$ of the students admitted to have problems with the characterizations. As it is found in the findings of this research, the students responded to the questions of the problem by stating that the problem was with the characterizations. It could be either creating or designing the characterizations, revealing the characterizations, or maintaining the characterizations throughout the story. As an attempt to cope with this problem, some students did a research for a character. This research was done by observing the real character or a real person, or it can be inspired from another fictional characters from movies or book. In the process of creating the theme, $69 \%$ of the students experienced the similar problems found in the creation of the plot, that whether or not the main idea of the story is unique or similar with the other stories. In coping with these problems, the students attempted to do research before deciding the theme and the plot. The research is done in form of reading from many resources. The major difficulty with the students is to deliver the details of the settings in a short story that provides limited room. In order to make the settings happened, the story had to be effective. This is done by various actions, such as providing an obvious scene, character's action, or an illustration that allows the student to dismiss the explanation of the setting. This is an effective way to provide the imagination of a scene without using too much description that ended up wasting a lot of space. The fifth element is the point of view. The majority of the problem found in the point of view is the choice between using the first person point of view or the third person point of view. About $38 \%$ of the students found that it is a hard choice in deciding the point of views due to the lack of experience the students had in fiction writing.

As this research is conducted for a beginner writer, therefore one element that cannot be separated is the technical problem. This technical problem which consists of grammar, sentence structure, and word choice comes as a consideration that this beginner writer is not a native speaker of English. The students of creative writing learn English as a foreign language, and therefore it affects the language use in the story. $77 \%$ of the students experienced problems with grammar, and $69 \%$ of the students experienced problems in arranging the sentence structure. The problem found in the grammar use is mostly caused by tenses confusion, meanwhile the main problem with the sentence structure is the level of sentence complexity which causes meaning confusion. The meaning confusion here means 
that it is either the sentence is too complex, too simple, or confusion that is caused by translation. Other than that, the students also dealt with the formality of the language, because the students mostly because the students learn English mainly for academic purposes. In addition, the problems also happened with the word choice. As the learner for English as a foreign language, the students' vocabulary and expression is limited. This is faced by $54 \%$ of the students, which stated that the problems with the word choices are the repetition of a certain words or the difficulty in varying the words.

Apart from the elements of literature and technical language problem, the issues also lay with the writers themselves. The factors which can influence the writers' performance in writing are distractions, writer's block, and mood. The distractions come for various reasons. About $85 \%$ of the students encountered problems with distractions, which is dominated by the students' other responsibility as a college students, as well as humanic possibility of having health issues, and therefore cannot be prevented. However, the other distractions come from personal actions, such as social life or social media, or hobbies that contain addictive entertainment (movies, games, etc.). Writer's block or known as the loss of ideas is also a major problem in writing. It is agreeable in this research that $100 \%$ the students experienced the problems with writer's block. In coping with this problem, the students did various actions, whether it is doing refreshing like taking a walk, doing further research, making new illustrations, or telling stories. All of these actions lead to one point where the students will come up with new ideas. The last issue raised in this discussion is mood, where it is debatable if it is the good mood or the bad mood which reduces and improves the writer's performance in writing. This confusion is supported by the finding of this research, that the majority of the respondent having an issue in bad mood during the writing process, and only one respondent experienced reduced performance because of the positive mood. In total, $69 \%$ of the students experienced problems in mood. The discussion about the link between the findings and the theories above leads into new assumptions, that each of the problems found in the aspects above as well as its solution is influential toward the writing performance. For instance, the difficulties in choosing the appropriate word choices might shows an indication of a word repetition throughout the story, which led to the need of better word choices. Another assumption is also shown by the students' mood during the writing process that the way the students writing in coping with the problem with negative mood might show an indication of a difference in language use and writing voice between the short stories made in a different mood.

\section{Conclusion}

This research found that the students of Short Story Production class had gone through the creative processes by experiencing problems, thus attempted to deal with those problems. The problems faced by the student involved three aspects, namely the literature aspects, the technical aspects, and the students' self-perception aspect, which later developed into eleven problems, namely plot, characterization, theme, settings, point of view, grammar, sentence structure, word choice, distraction, writer's block, and mood. The various problems found in this research resulting in various ways to deal with the problems, although it is also found that there are problems which have similar solutions from the students.

\section{Reference}

Andrew, D. W., \& Basuki, R. 2015. The Creative Process of Enarotali Dreams, A Screenplay. Journal of Literature, Language, and Teaching 3(4) p 85-89. Retrieved from: http://publication.petra.ac.id/index.php/sastra-inggris/article/view/4008/0

Akkaya, N. 2014. Elementary Teachers' Views on the Creative Writing Process: An Evaluation. Educational Sciences: Theory \& Practice 14(4). DOI: 10.12738/estp 
Alfaki, I. M. 2015. University Students' English Writing Problems: Diagnosis and Remedy. International Journal of English Language Teaching 3(3) p 40-52. Retrieved from: http://www.eajournals.org/wp-content/uploads/University-Students----English-WritingProblems-Diagnosis-and-Remedy.pdf.

Bogdan, R. C. \& Biklen, S. K. 2007, Qualitative Research for Education: An Introduction to Theory and Methods. Boston: Pearson Education Inc.

Brace, C. \& Putra, A. J. Recovering inspiration in the spaces of creative writing. Royal Geographical Society. Retrieved from: https://www.jstor.org/stable/40890995.

Brien, D. L. 2006. Creative Practice as Research: A Creative Writing Case Study. Media International Australia incorporating Culture and Policy. Retrieved from: http://journals.sagepub.com/doi/pdf/10.1177/1329878X0611800108.

Bruning, R., Kauffman, D., Dempsey, M. S., \& Zumbrunn, S. 2013. Examining Dimensions of Self-Efficacy for Writing. Journal of Educational Psychology, 105(1) p 25-38. DOI: 10.1037/a0029692

Curwood, J. S., Magnifico, A. M., \& Lammers, J. C. 2013. Writing in the Wild: Writers' Motivation in Fan-Based Affinity Spaces. Journal of Adolescent \& Adult Literacy 56(8) DOI:10.1002/JAAL.192

Farooq,M.S. \& Hassan,M.U. 2012. Opinion of Second Language Learners about Writing Difficulties in English Language. Research Journal of South Asian Studies, 27: 183$194 . \quad$ Retrieved from: https://www.researchgate.net/profile/Muhammad_Farooq108/publication/265561270_O pinion_of_Second_Language_Learners_about_Writing_Difficulties_in_English_Langua ge/links/56cdd9fd08ae85c8233e8413/Opinion-of-Second-Language-Learners-aboutWriting-Difficulties-in-English-Language.pdf

Forgeard, M. J. C. \& Mecklenburg, A. C. 2013. The Two Dimensions of Motivation and a Reciprocal Model of the Creative Process. Review of General Psychology, 17 (3), p 255-266. DOI: 10.1037/a0032104

Gotham Writers' Workshop Faculty. 2003. Writing Fiction: The Practical Guide from New York's Acclaimed Creative Writing School. Bloomsbury: New York and London.

Hynes, J. 2014. Writing Great Fiction: Storytelling tips and techniques. The Teaching Company: United States of America.

Kaufman, S. B., \& Kaufman, J. C. (2009). The psychology of creative writing. New York, NY, US: Cambridge University Press.

Koesnosoebroto, S. B. 1988. The Anatomy of Prose Fiction. Jakarta: Dirjen Dikti.

Mahendra, M. W. 2017. Realizing Learners' Writing Problem from the Beginning: A Case Study. ELLITE: Journal of English Language, Literature, and Teaching 2(1). Retrieved from: http://jurnal.unmuhjember.ac.id/index.php/ELLITE/article/view/759.

Morley, D. 2007. The Cambridge Introduction to Creative Writing. USA: Cambridge University Press.

Nasir, L., Naqvi, M., \& Bhamani, S. 2013. Enhancing Students' Creative Writing Skills: An Action Research Project. Acta Didactica Napocensia, 6(2). Retrieved from: https://eric.ed.gov/?id=EJ1053632. 
Ningrum, V., Rita, F. \& Hastini. 2013. Improving Writing Skill in Writing Recount Text through Diary Writing. English Language Teaching Society, 1(1), p 1-13. Retrieved from http://jurnal.untad.ac.id/jurnal/index.php/ELTS/article/view/1683.

Paton, Elizabeth. 2012. When the book takes over': creativity, the writing process and flow in Australian fiction writing. The International Journal of Creativity and Problem Solving, 22(1) $\mathrm{p} \quad 61-76 \quad$ retrieved from: https://link.galegroup.com/apps/doc/A446637862/AONE?u=googlescholar\&sid=AONE \&xid=83f40265. Accessed 14 Feb. 2019.

Tarnopolsky, Oleg. 2005. Creative EFL Writing as a Means of Intensifying English Writing Skill Acquisition: A Ukrainian Experience. TESL Canada Journal. Retrieved from: teslcanadajournal.ca.

Temizkan, M. 2011. The Effect of Creative Writing Activities on the Story Writing Skill. Educational Sciences: Theory \& Practice, 11(2), p 933-939. Retrieved from: https://eric.ed.gov/?id=EJ927384

Tok, S., \& Kandemir, A. 2015. Effects of creative writing activities on students' achievement in writing, writing dispositions and attitude to English. Procedia - Social and Behavioral Sciences. Retrieved from: https://www.sciencedirect.com/science/article/pii/S1877042815008678.

Tredinnick, M. 2006. The Little Red Writing Book. Australia: University of New South Wales.

Vickers, M. H. 2010. The Creation of Fiction to Share Other Truths and Different Viewpoints: A Creative Journey and an Interpretive Process. Qualitative Inquiry 16(7), p 556-565. DOI: $10.1177 / 1077800410371922$.

Zyoud, M. (2016). Theoretical Perspective on How to Develop Speaking Skill Among University Student. Journal education. Palestine 2(1). Retrieved from: https://www.researchgate.net/profile/Munther_Zyoud/publication/297013831_THEORE TICAL_PERSPECTIVE_ON_HOW_TO_DEVELOP_SPEAKING_SKILL_AMŌNG_UNI VERSITY_STUDENTS/links/56dc837f08aebe4638c031bf.pdf 